\title{
Perspectives on sustainable development and sustainability in the Canadian forest sector
}

\author{
by Brian Emmett ${ }^{1}$
}

\begin{abstract}
Decisions made about forest resources are increasingly dominated by concerns about limits, trade-offs, and diminishing returns from commodities. By focusing on sustainable development and the transformative power of human ingenuity, forest resources we need not regard as finite. The value of sustainable development lies in its power to place scientific and technical innovation into a dynamic framework relevant to those making policy and management decisions.
\end{abstract}

Key words: sustainable development, natural resources, limits, forest sector, commodities, innovation

\section{RÉSUMÉ}

Les décisions qui touchent les ressources forestières sont de plus en plus dominées par des questions de limites, d'échanges et de rendements décroissants à l'égard des produits de commodité. En nous concentrant sur le développement durable et la puissance de transformation de l'ingéniosité humaine, nous ne sommes pas tenus de considérer les ressources forestières comme limitées. La valeur du développement durable réside dans sa capacité de placer l'innovation scientifique et technique au sein d'un cadre dynamique et significatif pour les personnes qui établissent les politiques et qui prennent des décisions portant sur l'aménagement.

Mots clés : développement durable, ressources naturelles, limites, secteur forestier, produits de commodité, innovation

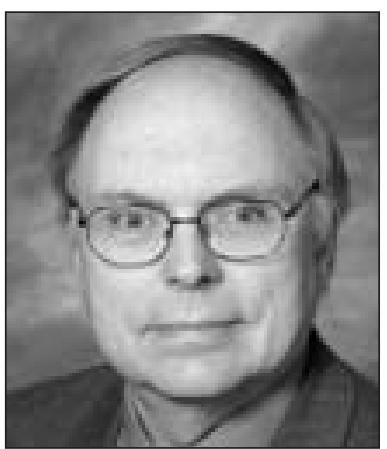

Brian Emmett
The concept of sustainable development (including its subset, sustainable resource management) has achieved near universal recognition as a functional and operational principle that provides guidance in formulating decisions within a wide range of management and policy issues. Commitment to the sustainable development of lands, water and resources has, over the past two decades, evolved to become one of the few fully shared objectives extending across all constitutionally defined resource jurisdictions in Canada. Reference to sustainable economic development is found in the mandates of federal, provincial and territorial natural resource and environment departments and in private sector forest resource organizations throughout Canada. For Natural Resources Canada and its sector, the Canadian Forest Service, sustainable development is both a formal legislative mandate and a day-to-day objective.

Acknowledged commitment to sustainable development aligns operational and research activities across the entire forest sector. Nevertheless, universal (or even majority) agreement as to the exact meaning of sustainable development and the implications of pursuing such continues to escape policy makers, resource managers and researchers alike. From the time of its inclusion within the 1987 report of the United Nations' World Commission on Environment and Develop- ment (WCED), Gro Harlem Brundtland's elegantly efficient definition - "development that meets the needs of the present without compromising the ability of future generations to meet their own needs" (Brundtland 1987) — has generated much agreement on the principle of sustainable development, less on its details, and in some quarters, no agreement at all on the concept's logical consistency. Explicit in the concept is the term "development" - the idea that human economic activity will create growth and wealth, but that such activity will not and must not alter the intergenerational hand-off of resources and environmental quality. Implicit is a requirement that a sustainable society and a sustainable environment are interdependent and intricately linked. Increasing use of economic arguments in the protection of environmental resources (Odling-Smee 2005) support the idea that economic and environmental sustainability are indeed two sides of the same coin.

Common understanding of an exact meaning has yet to emerge. After more than 20 years of road testing, quantifiable measure of the concept remains elusive. Some observers suggest sustainable development is best viewed as a moral and ethical issue rather than as a technical or scientific process for carrying out management or policy decisions (McCool and Stankey 2004). More strident detractors characterize sustainable development as a diversionary monster, a convenient sack dress, and a deception for conducting business as usual (Frazier 1997).

Given the confusion surrounding sustainable development, it is appropriate to revisit the origin of the term and its historical importance. During the 1970s and 1980s, considerable disruption in the world economy occurred, much of it

\footnotetext{
${ }^{1}$ Assistant Deputy Minister, Canadian Forest Service, Natural Resources Canada, 580 Booth St., Ottawa, Ontario K1A 0E4. E-mail: brian.emmett@nrcan-rncan.gc.ca
} 
generated by unease over the price and availability of natural resources. This was accompanied by growing concern that inadequate attention to the natural environment would result in widespread destruction of the world's air, water and soil. The Limits to Growth, the influential work commissioned by the global think tank Club of Rome, captured this concern and predicted a near future of shortage and decline for human society (Meadows et al. 1972). According to The Limits to Growth, the supply of resources was physically fixed, as was the capacity of the global environment to absorb the effects of human activities. Thus, individuals would have to adjust their economic expectations (downward) and the world would have to diffuse the human "population bomb." These were absolute requirements if humanity was to avoid abruptly running out of natural resources or drowning in its own waste.

The Limits to Growth focused attention on highly important policy issues, but had the unfortunate consequence of presenting a set of immutable choices that demanded there be winners and losers, or more frequently, only losers. Its inherent negativity and absence of options poisoned debate. In particular, developing countries began to view environmental concern as a thinly disguised plot against their own aspirations towards growth and development.

In response to such a polarized and unproductive debate, the WCED, through its release of the Brundtland report in 1987, did the world an enormous service by adopting an alternative approach - that of sustainable development. In doing so, it provided policy thinkers and individuals a means to reject the "win-lose" future predicted by The Limits to Growth and to develop a plan that recognized the important role that economic growth played in sustaining societies and the environment. Significantly, the report noted that the concept of sustainable development did imply limits, but that they were not absolute. They were limits to the present state of technology and social organization and limits to the ability of the biosphere to absorb the effects of human activities. Technology and social organization could be managed and improved to make the way for a new era of economic growth (Brundtland 1987). Resources were not finite, innovation and invention could increase wealth, and the concerns of the developing countries could be addressed through the incorporation of social justice as an integral component of sustainable development.

\section{Forest Sector Viewpoint}

From a forest science perspective, the details of sustainable development may still create discussion, but the sustainability component is comprehensible and one to which the profession (along with its sister science, agriculture) may legitimately lay claim. Though not a full equivalent of sustainable development, sustainable yield, the management of woodlands for the purpose of securing a timber crop in perpetuity, was a basic tenet of applied forest science from its beginnings. Increasing the quality and quantity of timber within an area was possible through the employment of silviculture, an innovative and technological skill. The relatively long period between planting and harvesting a tree in much of Canada's climate meant practising foresters did bequeath their efforts as a legacy to a future generation.
At the same time, the concept of "limits" became part of forestry's lexicon, captured in the term "timber limits," the area and quantity of forest resource to which a company or agency, through purchase or grant, had access. This usage requires some interpretation. Lumber baron J.R. Booth is reported to have at one time owned 11000 square kilometres of timber limits, or enough to make a strip 1.6 kilometres wide stretching across Canada from the Atlantic to the Pacific (Humber 1998).

\section{Are Forest Resources Limited?}

History aside, the key question for contemporary forest managers and policy makers is, given two contrasting views of the world, which one is "right"? Which one corresponds best to the current condition of Canadian and global forest resources? A view based on limits to growth has an intuitive appeal. Forests are dynamic; they are not fixed in a physical sense, although annual allowable cuts and forest commodity flows may be. It seems plausible that increasing demand could outstrip our ability to regenerate or sustain forest resources, and we could simply run out of supply. To resource professionals wrestling with issues of allocation, losses to disturbance, multiple use and a profoundly altered social licence, the forest resource may currently appear not just finite, but decreasing. Within this environment, decisions made about forests can easily be dominated by concerns about limits and characterized by trade-off, compromise and diminishing potential.

Sustainable development, however, presents a number of advantages as an alternative strategy. Whether in a forest management or policy development forum, it allows stakeholders with different priorities and principles to work together reasonably well on common problems. Limits to growth may initially seem the more plausible, precautionary and conservative approach, but only because it misses a critical variable - people and their talents.

From an economic point of view, resources, whether forest-based or otherwise, are not finite in any meaningful way because the transformative power of human ingenuity can make limits grow over time. Thus, while the world's population has grown rapidly, our ability to meet its need for food, resources and economic activity has increased even faster. In that context, the potential for products, services and contributions to public good from Canada's forests is not limited by immutable forces of nature, but is created by the minds and ingenuity of people. The proof of human history demands that Canadians alter their view of environmental, resource, and economic interactions by focusing on their ability to "grow" the limits of Canada's forest resources.

\section{Competition, Opportunity, and Challenge}

How are the global and domestic implications for the Canadian forest sector to be interpreted using sustainable development as a starting point? History provides some answers to this question. The forest sector has evolved, and is continuing to evolve, through distinct phases (Cohen and Kozak 2001). Initially, forest harvesting dominated innovation and research and technology focused on improving the extraction of trees from the forest. This was followed by a focus on production, and technology was employed to 
improve productivity and reduce manufacturing costs. Most recently, and most significantly, the sector has begun to concentrate on marketing. It has recognized that, in a fiercely competitive global market, forest companies must be primarily responsive to customers and to their particular needs for innovative products and process development.

Increasing and accelerating this momentum towards a product-driven sector is critical, even at risk of abandoning a long-held assumption — that Canada's forestry advantage lies in its extensive capacity to provide high-quality fibre in volume. The reality is that Canada's global competitors have developed similar capacities. The fibre market is a commodity market, characterized by ever-increasing supply, a demand for continual gain in output efficiency, and ever-downward pricing. Given current poor returns on capital employed and eroding market share, incentives for reinvestment in the sector are becoming limited. In a cost-cutting spiral of volume commodity production, research and development tend to be viewed as a cost rather than an investment, and our abilities to grow the limits are compromised. Left unaddressed, more and more of Canada's production will slide into a high-cost category that will not survive cyclical waves of commodity pricing. The historical reality of sustainable development is that not only limits can be grown, but that the price of resources steadily declines over time. For the Canadian forest sector, the traditional advantage is likely to become a blind alley.

Canada's forest industry has certainly benefited from past technological advancements. It developed hardwood pulping, oriented strandboard, and sawmills capable of efficiently using small-dimensional wood, as well as new products made from available and lower-value tree species. Refinement of these advances is ongoing, but they are reaching the margin of potential for improvement. New and dynamic solutions are required.

Beyond technical advancement, focus on innovation and ingenuity serves the Canadian sector by enabling access to a global marketplace that is increasingly conscious of environmental sustainability. To this end, Canadian pulp and paper mills have reduced carbon dioxide emissions by $26 \%$ since 1990. In 2001, 57\% of the forest sector's energy use came from biomass fuel. Perhaps most impressive of all, Canada has become a world leader in the certification of sustainably managed forest land, going from no areas with third-party certification in 1998 to 46.5 million hectares of certified area in 2003.

Achieving a new and long-term competitive advantage will require a focus on innovation and the creation of valueadded products. Canada's forest sector must take advantage of the knowledge and expertise of Canadians to expand its current strategies and create options for the future. The greatest opportunity lies in combining the market intelligence and expertise used along the forest product supply chain with the unique and diverse characteristics of the fibre resource. Through sustainability-driven innovation, the forest sector can increase the economic value of the forest resource over time, and industry can demonstrate its viability and integrity to others. Further, the forest sector needs to determine the limiting factors in Canadian forests - their productivity, species composition, wood traits and so on - and overcome these limits by developing value-added products. Science and technology directed to the development of innovative value- added products at the retail end of the supply chain and at the forest stand level will "grow" the limits that will best benefit both the sector and Canada.

Such an approach is specifically noted and encouraged by the National Forest Strategy 2003-2008, in its suggestion that Canada stimulate diversification of markets, forest products, services and benefits (timber and non-timber) by understanding current and emerging markets; developing new domestic and international markets; promoting value-added products and the optimization of wood use; attracting manufacturers of finished products; and finding markets for forest environmental services (National Forest Strategy Coalition 2003).

A wide range of new opportunities exists for the sector. Non-timber products including biomedicines and nutraceuticals (natural, bioactive chemical compounds that have properties to promote health and prevent disease) can be developed from Canada's forests, creating and expanding markets. Eco-tourism and geo-tourism are developing as "light footprint" industries. Different and more comprehensive inventories of forest assets will be required to fully benefit from these novel forest services and to better develop and diversify the forest-based economy.

Aboriginal peoples have a unique perspective on forests and forest lands, central to Aboriginal culture, spirituality, lifestyle and income. Their perspective and knowledge contribute to innovation and create economic opportunity. Currently, forestry and allied industries are the principal economic activity and primary source of earned income for $80 \%$ of First Nation communities. Aboriginal workers comprise $5.9 \%$ of all workers in the forest sector, compared with $2.3 \%$ for all industries. The ongoing negotiation of resource rights and treaties will change the forest landscape in Canada by increasing the area of forest available for First Nations to use for their own purposes. Innovative ways to derive value from the forest resource, either through traditional or non-traditional products and services, will be a key to their success.

Natural Resources Canada and the Canadian Forest Service are committed to sustainable development and are thus in the business of pushing the limits. The challenge for the forest sector, and its best opportunity to contribute to the process, is to set priorities based on sustainable development. The forest sector can meet that challenge by encouraging the development of new and better technologies — innovations that do more with less or substitute abundant materials for those that are scarce. It can develop information systems and resource inventories that are comprehensive and more userfriendly to give people, firms and governments a better understanding of options and an opportunity to make better decisions. Managing existing resources more efficiently is as beneficial as inventing an entirely new physical process. Smart regulations, those that enable the same environmental result in a less costly way, should be a priority for policy development and management. It rarely makes sense to do things that one can do well badly, particularly in pursuit of sustainability. Poor policies and poor coordination among government departments destroy wealth without a corresponding environmental benefit. The value of sustainable development lies in its power to place the scientific and technical work performed by Canadians in the forest sector into a dynamic 
framework relevant to those making policy and management decisions.

Canada is steward to a vast and diverse natural forest endowment. This country has pioneered a unique regime of sustainable forest management practices that differ from the approaches taken by other forest management jurisdictions in the world. Canada's definition of forests extends beyond natural legacy or natural capital. Forests in Canada are seen as an essential public good and a contributor to a progressive modern economy - a view that also has relevance globally.

The best way to sustain forests is to ensure the growth and economic sustainability of the forest sector. By doing so, Canada creates a coherent policy approach that meets not only its objectives, but also responds to the overwhelming needs of developing countries. If Canada takes the opposing view, that sustainability lies in imposing limits, then developing countries will reject its policies and stewardship concerns.

The forest sector is currently wrestling with enormous challenges. Along with the imperative to succeed in an increasingly unforgiving global marketplace, the sector is required to make decisions while facing great uncertainty. A changing climate and invasive alien species are but two of the threats with the potential to degrade the health, composition and economic value of Canada's forests. Such challenges are made all the more frightening because they are impossible to predict and difficult to manage.

Nevertheless, as the economist Julian Simon has observed, "the ultimate resource is the human imagination..." and "the only likely limit upon the production of new knowledge about resources is the occurrence of new problems; without unsolved problems there will be no solutions" (Simon 1996).
The solutions the forest sector seeks will extend beyond trees, forests and landscapes. They will be provided by people who possess intellect, adaptability, scientific knowledge, and the creative insight necessary to meet the needs of an increasingly complicated world. Human ingenuity has the power to increase the economic value of forest resources over time and push the limits beyond current constraints.

\section{References}

Bruntland, G. (ed.). 1987. Our Common Future: The World Commission on Environment and Development. Oxford University Press, Oxford.

Cohen, D.H. and R.A. Kozak. 2001. Research and technology: market-driven innovation in the twenty-first century. The Forestry Chronicle 78(1): 108-111.

Frazier, J.G. 1997. Sustainable development: modern elixir or sack dress? Environmental Conservation 24(2): 182-193.

Humber, C.J. (ed.). 1998. Visionaries: Canadian Triumphs. Vol. VI. Canada Heirloom Series. Heirloom Publishing, Mississauga, ON.

McCool, S. and G.H. Stankey. 2004. Indicators of sustainability: challenges and opportunities at the interface of science and policy. Environmental Management 33(3): 294-305.

Meadows, D.H., D.I. Meadows, J. Randers and W.W. Behrens III. 1972. The Limits to Growth. The Club of Rome, Universe Books, New York.

National Forest Strategy Coalition. 2003. National Forest Strategy 2003-2008. A Sustainable Forest: The Canadian Commitment. Ottawa.

Odling-Smee, L. 2005. Dollars and sense. Nature 437: 614-616.

Simon, J.L. 1996. The Ultimate Resource 2. Princeton University Press, Princeton, NJ. 